\title{
ERF wt Allele
}

National Cancer Institute

\section{Source}

National Cancer Institute. ERF wt Allele. NCI Thesaurus. Code C52226.

Human ERF wild-type allele is located in the vicinity of $19 q 13$ and is approximately $7 \mathrm{~kb}$ in length. This allele, which encodes ETS domain-containing transcription factor ERF protein, is involved in transcriptional modulation. 